\title{
A Statistical Study of the Impact of Active Learning on Students' Learning Attitudes toward Physics Based on the CLASS-Phys Survey
}

\author{
Xin Gao
}

\begin{abstract}
In this study, the well-known Colorado Leaning Attitudes about Science Survey (CLASS) instrument was used to assess the effectiveness of the Active Learning teaching method. The survey results show Active Learning manifestly improved students' learning attitudes toward physics. ANOVA tests were further conducted to study the statistical significance of those differences. The tests show that in the class taught using Active Learning method, the differences before and after taking the course are statistically significant at a 0.05 level of significance. However, the differences between the traditional and Active Learning teaching methods are not always as statistically significant as expected at a 0.05 level of significance. The high diversity in students' academic backgrounds at LaGuardia Community College is considered to be the main reason explaining this outcome because ANOVA tests compare the variances within and among the groups. The high diversity within the groups may have dwarfed the variance among the groups.
\end{abstract}

Index Terms-Undergraduate physics education, ANOVA test, CLASS-Phys survey, active-teaching/learning.

\section{INTRODUCTION}

There have been extensive pedagogical researches conducted on why and how to improve the effectiveness of undergraduate STEM education over the years [1]-[8]. Active Learning has been discussed for decades as an alternative method for STEM education to the traditional lecture-based teaching method [9]-[13]. However, the definition of Active Learning varies among pedagogical research papers. For example, Prince's review paper [14] listed Active Learning as an approach parallel to collaborative learning, cooperative learning and problem-based learning (PBL). Among these teaching methods, Active Learning is defined specifically as "any instructional method that engages students in the learning process." More specifically "Active Learning requires students to do meaningful learning activities and think about what they are doing [9]." An example of Active Learning discussed in the paper is "for the lecturer to pause periodically and have students clarify their notes with a partner. This can be done two or three times during an hour-long class."

In contrast, some research papers [9], [15] defined Active

Manuscript received July 13, 2019; revised September 25, 2019.

Xin Gao is with the Natural Sciences Department of LaGuardia Community College of The City University of New York (CUNY), Long Island City, NY 11101, USA (e-mail: Xgao@lagcc.cuny.edu).
Learning as "engages students in the process of learning through activities and/or discussion in class, as opposed to passively listening to an expert. It emphasizes higher-order thinking and often involves group work." Michel et al. listed experiential learning, problem-based learning, participative learning and cooperative learning as approaches for Active Learning [16].

In this research paper, we will discuss Active Learning as defined in Freeman's paper [17] and include both in-class activities and group discussions as Active Learning practices in the classroom.

The effectiveness of Active Learning has also been extensively studied. Some researches were focused on examination scores or failure rates [13], [16]; some were focused on students' satisfaction with the class. For example, Stewart-Wingfield and Black [18] reported that student Active Learning helps students perceive their learning in class more relevant and is helpful for their future class.

This paper will focus on the impact of Active Learning on students' learning attitude toward physics. Colorado Learning Attitudes about Science Survey (CLASS) was used in this research. Students were asked to take the survey at the beginning and at the end of the semester when they take the Topics in Physical Sciences (SCP101) -an introductory physics course at LaGuardia Community College of The City University of New York. To quantitatively assess the effectiveness of Active Learning, this paper will conduct statistical analysis on the CLASS survey results collected from two groups of students: one taught using traditional lecture-based teaching method; and the other taught using Active Learning method, at the beginning and end of the semester when they take the introductory physics course (SCP101).

\section{METHOD}

\section{A. The Course under Study}

The course targeted in this research is Topics in Physical Sciences (SCP101) at LaGuardia Community College of the City University of New York (CUNY). It is an introductory physics course for non-majors to meet the "Scientific World" category in students' curricula. Professors usually have more flexibilities in deciding the depth and range of topics they cover in this course than in other required physics courses for STEM majors.

In this research, students' learning attitudes about physics 
were studied before and after taking the SCP101 course taught using two different teaching methods: traditional lecture-based instructional method and Active Learning method.

In the class taught using the traditional teaching method, the professors gave a 3-hour lecture every week without students' active involvement. Most time, the professor lectured and the students listened passively.

In the Active Learning method, the professor gave a more focused and concise lecture (usually 1.5-2 hours) and leave time for students to do in-class exercises, group discussions or hands-on activities (examples will be given in the following sections).

\section{B. Example Active Learning Activities}

In-class activities are designed and implemented in the classroom to help students apply and better understand concepts, definitions, principles and laws discussed in the lecture part of each class. It is also the major difference between the traditional lecture-based teaching method and the Active Learning method. Following are some example activities implemented in the classroom.

1) Example in-class exercise:

In the "Heat and Temperature" topic, to help students understand temperature change and phase change substances experience when being heated, the following example problem was given and students were asked to think and solve the problem either individually or work in pairs.

Given specific heat capacity of water as $1 \mathrm{cal} / \mathrm{g}^{\circ} \mathrm{C}$, specific heat capacity of ice as $0.5 \mathrm{cal} / \mathrm{g}^{\circ} \mathrm{C}$, and latent heat of fusion of water is $80 \mathrm{cal} / \mathrm{g}$, how much heat is needed to transform a $1 \mathrm{~kg}$ block of ice at $-5^{\circ} \mathrm{C}$ to a puddle of water at $10^{\circ} \mathrm{C}$ ?

A common mistake that student tend to make in solving this problem is to calculate the total required heat in one step without thinking about the two different processes: temperature change and phase change. By trying to solve this problem in class and getting immediate feedback on their work from peers or the professor, students will gain a better understanding about why and how to break the question into 3 processes: a) bring ice to its melting point by adding heat; b) completely melting the ice; c) increasing the temperature of melted liquid water to a certain degree above the melting point.

This kind of in-class exercises not only help students interact with the professor and their peers, but also help engage students and provide opportunities for students to practice what they just learned in class.

2) Example in-class discussion:

Student are provided a list of appliances with their electricity (energy) consumption per month (Table I) and asked to form a group of 2 or 3 to have guided discussions on the following questions:

a) Using the above chart as a guide, think about the appliances you have at home, find them in the chart and list them below:

b) What does kwh mean? How much is $1 \mathrm{kwh}$ in Joules? c) Calculate the electricity bill you expect to get based on the appliances you have at home. Assume the electricity rate of charge is 8.5 cents $/ \mathrm{kwh}$.

d) If you change your light bulb from a 100watt regular light bulb to a 20 watt energy-efficient light bulb, how much money would you save every month?

e) What does energy-efficient mean? Do we get the same brightness from a 100-watt traditional light bulb and a 20-watt energy-efficient bulb which is claimed to be equivalent to a 100-watt traditional light bulb? Do they consume the same amount of energy in a given amount of time? How is energy/money saved?

TABLE I: LIST OF APPLIANCES WITH THEIR ELECTRICITY (ENERGY)

\begin{tabular}{|c|c|c|}
\hline CONSUMPTI & $\begin{array}{l}\text { ON PER MONTH } \\
\text { Time in use }\end{array}$ & kWh/month \\
\hline Clock radio & 24 hours per day & 3.6 \\
\hline Clothes dryer & 5 Loads per week & 100 \\
\hline Clothes washer (cold water) & 5 loads per week & 10 \\
\hline Coffee maker & 2 hours per day & 45 \\
\hline Dehumidifier & 12 hours per day & 216 \\
\hline $\begin{array}{l}\text { Dishwasher } \\
\text { (does not include hot water) }\end{array}$ & 1 hour per day & 36 \\
\hline Electric blanket & 960 hours per year & 24 \\
\hline Fan (furnace) & 12 hours per day & 93 \\
\hline Fan (window) & 4 hours per day & 24 \\
\hline Fan (whole house) & 4 hours per day & 67.5 \\
\hline Hair dryer & 15 minutes per day & 11.6 \\
\hline Heater (1,500 watt) & 3 hours per day & 140 \\
\hline Hot tub & Mild weather & 400 \\
\hline Iron & 1 hour per week & 6 \\
\hline Toaster oven & 1 hour per day & 46 \\
\hline Microwave oven & 30 minutes per day & 18.6 \\
\hline Oven & 1 hour per day & 108 \\
\hline Pool pump 2 hp & 24 hours per day & 1,116 \\
\hline Radio (stereo) & 2 hours per day & 6.1 \\
\hline Refrigerator $26 \mathrm{Cu}$. Ft (Energy Star) & 24 hours per day & 48.5 \\
\hline Television $42^{\prime \prime}$ LCD & 5 hours per day & 11 \\
\hline Water bed (no cover) & 12 hours per day & 103.3 \\
\hline Water heater ( 40 gallon) & 1 person & 252 \\
\hline Water pump (deep well) & 2 hours per day & 90 \\
\hline Vacuum cleaner & 1 hour per week & 3.1 \\
\hline VCR, DVD & 4 hours per day & 12.4 \\
\hline 100 watt light bulb & 6 hours per day & 18.6 \\
\hline 25 watt CFL bulb & 6 hours per day & 4.65 \\
\hline 175 watt Mercury vapor bulb & 300 hours per month & 52.5 \\
\hline
\end{tabular}

Table cited from

https://www.myrec.coop/share/save-energy/Typical-Energy-Use.cfm

\section{The CLASS Survey}

The CLASS Survey refers to the Colorado Learning Attitudes about Science Survey. It was developed and validated in the University of Colorado Boulder. There are three sets of survey questions: CLASS-Phys, CLASS-Chem, and CLASS-Bio for three disciplines: physics, chemistry and biology, respectively.

In the CLASS-Phys survey, there are 42 questions in total. Each question is a statement/claim on learning attitudes about physics. Twelve questions that are most relevant to this study and most interesting to the author were selected as the questions under investigation. In answering these questions, students rate the statement/claim on a scale of 5 , with 1 meaning strongly disagree and 5 meaning strongly agree.

Questions can be categorized and assess different aspects of students' learning, such as: Real World Connection, Personal Interest, Sense Making/Effort, Conceptual Connections, Applied Conceptual Understanding, Problem 
Solving General, etc. [19]. Revised Categories include: Personal Application and Relation to Real World, Problem Solving/Learning, Effort/Sense Making [20]. Below is a list of the selected questions and the different aspects of student learning attitudes these questions are used to test respectively:

- Real World Connection: 28, 30, 35, 37

- Personal Interest: 14, 25, 28, 30

- Sense Making/Effort: 32

- Conceptual Connections: 32

- Problem Solving - General: 25, 26

\section{Data Collection and Sample Sizes}

It is assumed that students that register for the Topics in Physical Sciences (SCP101) course at LaGuardia Community College come from the same statistical population, which means there is no statistically significant difference among students entering different sections (classes taught by different professors using different teaching methods) of the SCP101 course. CLASS-Phys survey data of students taught using the two different teaching methods were collected before and after taking the SCP101 course. All the survey questionnaires collected at the very beginning of the semester served as the pre-survey sample; questionnaires collected at the end of the semester of SCP101 course in the class using traditional lecture-based teaching method serve as the post-without Active Learning (AL) sample; and questionnaires collected at the end of the semester of SCP101 course in the class using Active Learning method teaching serve as the post-with AL sample. The sample sizes for each group is as follows:

- Pre- sample Size: 43

- Post- without AL sample size: 18

- Post- with AL sample size: 33

\section{DATA AND ANALYSIS}

As motioned in the previous section, questions in the CLASS-Phys survey can be categorized and assess different aspects of students' learning attitudes. Questions selected from different categories were examined to compare the impact of Active Learning.

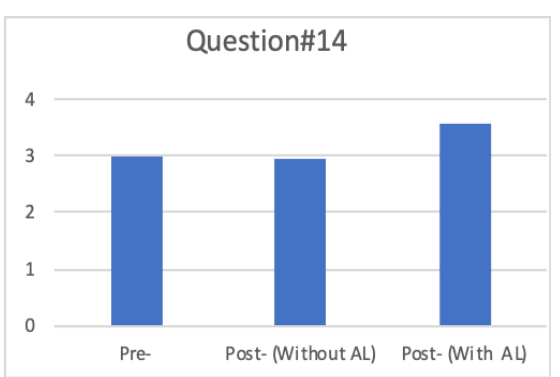

Fig. 1. The average scores of the three samples on questions \#14: I study physics to learn knowledge that will be useful in my life outside of school $(+)$.

The average score on each question of the two groups of students (the Pre-sample, the Post-without AL sample, and the Post-with AL sample) are illustrated in bar charts. At the end of the figure caption of each question, (+) symbol means that the higher the score, the more effective the teaching is considered to be in that aspect described in the question; (-) symbol means that the lower the score, the more effective the teaching is considered to be in that aspect described in the question; * means that the difference is statistically significant at a level of significance (alpha) of 0.1 ; and ** means that the difference is significant at a level of significance (alpha) of 0.05 .

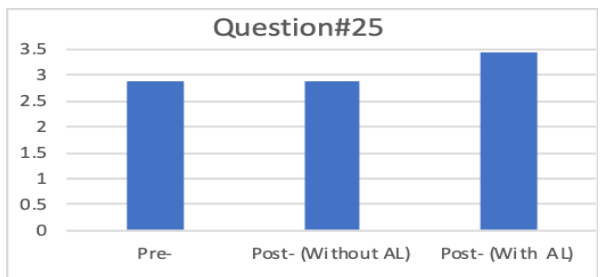

Fig. 2. The average scores of the three samples on questions \#25: I enjoy solving physics problems $(+)$

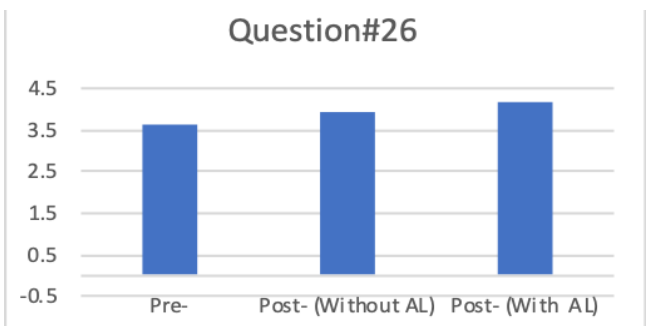

Fig. 3. The average scores of the three samples on questions \#26: In physics, mathematical formulas express meaningful relationships among measurable quantities $(+) *$

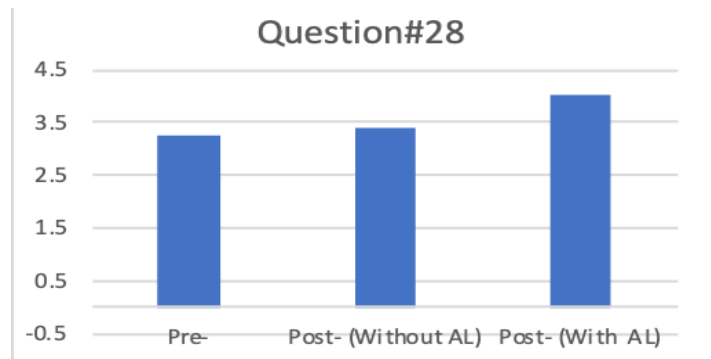

Fig. 4. The average scores of the three samples on questions \#28: Learning physics changes my ideas about how the world works $(+) * *$

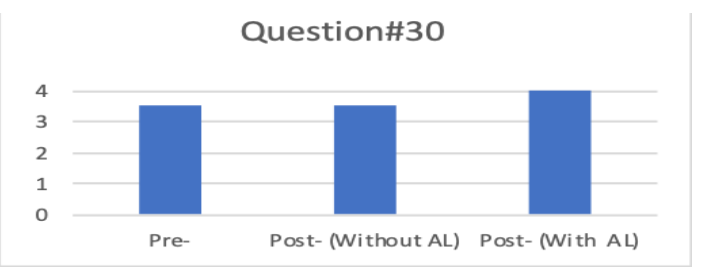

Fig. 5. The average scores of the three samples on questions \#30: Reasoning skills used to understand physics can be helpful to me in my everyday life (+) *

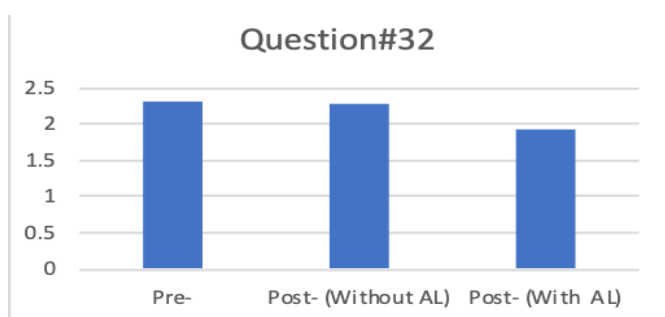

Fig. 6. The average scores of the three samples on questions \#32: Spending a lot of time understanding where formulas come from is a waste of time (-).

As shown in the figures above, the teaching method with Active Learning activities scores better than both the pre-surveys and the post-surveys without Active Learning activities for all the selected questions. To study whether or 
not the differences are statistically significant, ANOVA tests were conducted to compare among the pre- survey, the postsurvey without Active Learning activities, and the post-survey with Active Learning activities. Below is a summary of the p-values of the ANOVA tests:

\begin{tabular}{|c|c|c|c|}
\hline \multirow{2}{*}{$\begin{array}{l}\text { Question } \\
\text { Number }\end{array}$} & \multicolumn{3}{|c|}{ ANOVA test $($ alpha $=0.05)$ p-value } \\
\hline & $\begin{array}{l}\text { Compare Pre- } \\
\text { with } \\
\text { Post-without } \\
\text { AL }\end{array}$ & $\begin{array}{l}\text { Compare Pre- with } \\
\text { Post-with AL }\end{array}$ & $\begin{array}{l}\text { Compare } \\
\text { Post-without AL } \\
\text { with post-with } \\
\text { AL }\end{array}$ \\
\hline 14 & 0.883643 & 0.054581 & 0.096084 \\
\hline 25 & 0.988777 & 0.078114 & 0.192885 \\
\hline 26 & 0.30703 & 0.010342 & 0.434783 \\
\hline 28 & 0.739557 & 0.002506 & 0.030415 \\
\hline 30 & 0.99314 & 0.038766 & 0.07698 \\
\hline 32 & 0.92534 & 0.120074 & 0.290848 \\
\hline 35 & 0.65551 & 0.304405 & 0.220678 \\
\hline 37 & 0.494546 & 0.002585 & 0.092493 \\
\hline 42 & 0.232518 & 0.370943 & 0.724385 \\
\hline
\end{tabular}

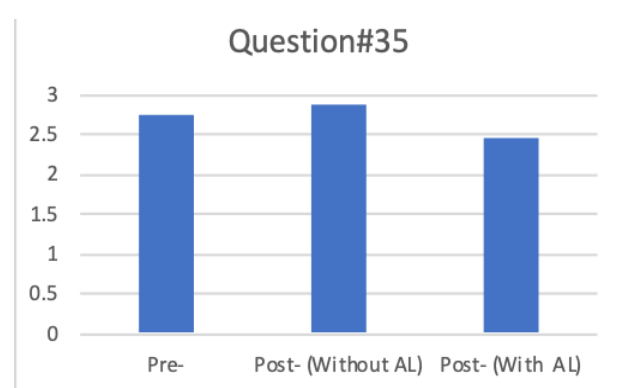

Fig. 7. The average scores of the three samples on questions \#35: The subject of physics has little relation to what I experience in the real world (-).

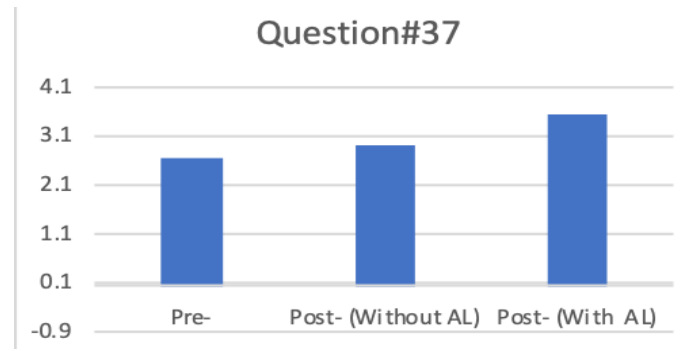

Fig. 8. The average scores of the three samples on questions \#37: To understand physics, I sometimes think about my personal experiences and relate them to the topic being analyzed $(+) * *$.

As shown in Table I, at the 0.05 level of significance, there is statistically significant differences between students' rating scores on questions $26,28,30$, and 37 before taking course SCP101 and after taking the course in the class taught with Active Learning method. However, there is no statistically significant differences between students' rating scores on all the selected questions before taking course SCP101 and after taking the course in the class taught with traditional lecture-based teaching method in which no Active Learning activities were implemented in the classroom.

Another finding is that even though there are evident differences between students' rating scores on all the selected questions between the Active Learning method and the traditional lecture-based teaching method, only the difference for question 28 is statistically significant at a level of significance of 0.05 . A possible reason is that diversity in students' academic background at LaGuardia Community College is so large (for example, some students have taken more than 3 years of physics in their home country, while some other students never took any physics course before entering LaGuardia Community College) that it dwarfs the differences between the Active Learning method and the traditional lecture-based teaching method.

\section{CONCLUSION}

This research showed that Active Learning is more effective in improving various aspects of students' learning attitudes toward physics, especially in helping students make real-world connection (question 28, 30 and 37), promoting students' interests in physics (question 25, 28, and 30), and improving students' problem-solving abilities (question 26).

The ANOVA test conducted on scores on question 28 of the CLASS-Phys survey shows statistically significant evidence of a difference between the traditional lecture-based teaching and Active Learning methods. However, the difference shown in other questions were evident but not statistically significant at a level of significance of 0.05 . A possible reason is that diversity in students' academic background at LaGuardia Community College is so large that it dwarfs the differences between the Active Learning method and the traditional lecture-based teaching method.

\section{PROPOSAL FOR FUTURE WORK}

Future study will take students' academic backgrounds into consideration. At the same time, the author will conduct the CLASS-Phys survey and the corresponding statistical analyses on enlarged samples.

\section{CONFLICT OF INTEREST}

The author declares no conflict of interest.

\section{AUTHOR CONTRIBUTIONS}

Dr. Gao conducted the research; analyzed the data; wrote the paper by herself.

\section{ACKNOWLEDGMENT}

Special thanks to Dr. Jaime Nieman of the Natural Sciences department of the LaGuardia Community College of CUNY for conducting the CLASS-Phys survey in one of his SCP101 classes.

\section{REFERENCES}

[1] National Commission on Excellence in Education, A Nation at Risk: The Imperative for Reform, Washington, DC: Government Printing Office, 1983.

[2] E. P. Volpe, "The shame of science education," Am Zoologist, vol. 24, pp. 433-441, 1984.

[3] Association of American Medical Colleges, "Physicians for the twenty-first century," The GPEP Report, Washington, DC: Association of American Medical College, 1984.

[4] National Research Council Committee on High School Biology Education, Fulfilling the Promise: Biology Education in the Nation's Schools, Washington, DC: National Academy, 1990.

[5] National Research Council Committee on Undergraduate Biology Education to Prepare Research Scientist for the $21^{\text {st }}$ Century, Bio2010: Transforming Undergraduate Education for Future Research Biologist, Washington, DC: National Academy, 2003. 
[6] J. A. Michael and H. I. Modell, "Active learning in secondary and college science classrooms: A working model of helping the learning to learn," Mahwah, NJ: Erlbaum, 2003.

[7] H. I. Modell and J. Michael, "Promoting active learning in the life science classroom," Annals of the New York Academy of Sciences, vol. 701, no. 1, pp. 1-7, December, 2006.

[8] D. F. Halpern and M. D. Hakel, "Learning that lasts a lifetime: Teaching for retention and transfer," New Dir Teach Learn, vol. 89, pp. 3-7, 2002.

[9] C. C. Bonwell and J. A. Eison, "Active learning: Creating excitement in the classroom," ASHEERIC Higher Education Report, no. 1, George Washington University, Washington, DC, 1991.

[10] J. Benek-Rivera and V. E. Matthews, "Active learning with jeopardy: Students ask the questions". Journal of Management Education, vol. 28, no. 1, pp. 104-118, 2004.

[11] A. Dorestani, "Is interactive Learning superior to traditional lecturing in economics courses?" Humanomics, vol. 2, no. 1, pp. 1-20, January, 2005.

[12] Y. Sarason and C. Banbury, "Active Learning facilitated by using a game-show format or who doesn't want to be a millionaire?" Journal of Management Education, vol. 28, no. 4, pp. 509-519, 2004.

[13] D. Ebert-may, C. Brewer, and S. Allred, "Innovation in large lectures and teaching for active learning," Bioscience, vol. 47, no. 9, pp. 601-607, 1997.

[14] M. Prince, "Does active learning work? A review of the research," J. Engr. Education, vol. 93, no. 3, pp. 223-231, 2004.

[15] S. Freeman, S. L. Eddy, M. McDonough, M. K. Smith, N. Okoroafor, H. Jordt, and M. P. Wenderoth, "Active learning increases student performance in science, engineering, and mathematics," in Proc. the National Academy of Sciences, vol. 111 no. 23, 8410-8415, June 2014.

[16] N. Michel, J. Cater, and O. Varela, "Active versus passive teaching styles: An empirical study of student learning outcomes," Small Business Institute National Proceedings, vol. 33, no. 1, pp. 55-67, winter 2009.

[17] S. Freeman, S. L. Eddy, M. McDonough, M. K. Smith, N. Okoroafor, H. Jordt, and M. P. Wenderoth, "Active learning increases student performance in science, engineering, and mathematics," in Proc. the National Academy of Sciences, vol. 111 no. 23, pp. 8410-8415, June, 2014.

[18] S. S. Winfield and G. S. Black, "Active versus passive course design: The impact on student outcomes," Journal of Education for Business, vol. 81, no. 2, pp. 119-125, 2005.

[19] L. Crocker and J. Algina, Introduction to Classical and Modern Test Theory, Wadsworth Publishing Co., Cengage Learning, Stamford, CT, 2006.

[20] K. A. Douglas, M. S. Yale, D. E. Bennett, M. P. Haugan, and L. A. Bryan, "Evaluation of colorado learning attitudes about science survey," Physics Review Special Topics-Physics Education Research, vol. 10, 2014.

Copyright $\odot 2019$ by the authors. This is an open access article distributed under the Creative Commons Attribution License which permits unrestricted use, distribution, and reproduction in any medium, provided the original work is properly cited ( $\underline{\text { CC BY 4.0). }}$.

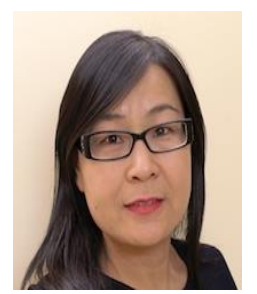

Xin Gao obtained her Ph.D. in physics from the Graduate Center of The City University of New York (CUNY). Her PhD thesis was focused on the interface of physics, mathematics, and finance. In that research she used techniques from mathematics and physics to develop pricing models for financial derivatives. The work was published in the International Journal of Financial Engineering in 2017. Dr. Gao also has rich research experience in experimental physics and has published her work in different peer-reviewed journals.

Before joining LaGuardia Community College of the City University of New York, Dr. Gao worked as an adjunct assistant professor at the Fashion Institute of Technology of the State University of New York (SUNY), Baruch College and Borough of Manhattan Community College (BMCC) of The City University of New York. Currently, she is focusing on pedagogical research on undergraduate STEM education and experimental biophysics research using fluorescence spectrophotometer.

Selected Publications:

1) Xin Gao and Binlin $\mathrm{Wu}$, "Breast cancer diagnosis using fluorescence spectroscopy with dual-wavelength excitation and machine learning," Proceedings of SPIE 10873, Optical Biopsy XVII: Toward Real-Time Spectroscopic Imaging and Diagnosis, 10873F, March 2019

2) Binlin Wu, Xin Gao, and Jason Smith, "Optical biopsy for prostate cancer diagnosis using fluorescence spectroscopy," International Journal of High-Speed Electronics and Systems, vol. 27, no. 3\&4, 1840026 (8 pages), 2018

3) Binlin $\mathrm{Wu}$, Jason T. Smith, Lin Zhang, Xin Gao, Robert R. Alfano, "Characterization and discrimination of human breast cancer and normal breast tissues using resonance Raman spectroscopy", Proc. SPIE 10489, Optical Biopsy XVI: Toward Real-Time Spectroscopic Imaging and Diagnosis, 104890X (19 February 2018)

4) Xin Gao, Binlin Wu, Tobias Shaefer. "Introducing an Analytical Solution and an Improved One-Factor Gaussian Copula Model for the Pricing of Heterogeneous CDOs" International Journal of Financial Engineering 04, 1750038 (17 pages), 2017

5) Binlin Wu, Kevin Dahlber, Xin Gao, el al. "Rapid measurement of meat spoilage using fluorescence spectroscopy", International Journal of High-Speed Electronics and Systems, vol. 27, no. 3\&4, pp. 1840025 (9 pages), 2018

6) Xin Gao and Brian Schwartz, "Classroom Implementation of Active Instructional Strategies for Undergraduate STEM Education", International Journal of Information and Education Technology, Vol. 5, No. 9,2015

7) X. Gao, Z.B. Deng, D.L. Tao, "Luminescence Properties of a New Kind of Rare Earth Complexes", Journal of The Chinese Rare Earth Society, 19 (6) 2001

8) X. Gao, Z.J. Wang, Z.B. Deng, "Energy Transfer from PVK to Europium Complex in Electroluminescence", Journal of The Chinses Rare Earth Society, 20 (2) 2002 